\title{
Angela Locatelli
}

\section{Plurivocal Narration as an Empathetic Response of Resistance to Colonial Prejudice.} Writing Alterity in The Voyage Out

\begin{abstract}
I: Questo saggio intende chiarire come la letteratura possa promuovere un”Etica dell'immaginazione empatica'. I testi letterari illustrano e spesso invitano all'accettazione di valori socialmente condivisi, ma possono anche, altrettanto spesso, tradursi in una sfida alla logica di tali valori, non solo a livello dei personaggi e dei loro comportamenti ma a partire dallo speciale uso del linguaggio e delle strategie narrative messi in atto dallo scrittore. La complessa plurivocità del letterario consente infatti la percezione di soggettività molto diverse e diviene efficace strumento di resistenza al pregiudizio consentendo un approccio più approfondito all'esperienza dell'alterità. Queste tesi verranno riprese in riferimento a The Voyage Out di Virginia Woolf. Un'attenzione particolare verrà data al divario tra le posizioni del narratore e quelle dei personaggi in quanto strumentale all'empatetica critica woolfiana al colonialismo.
\end{abstract}

Abstract II: This essay proposes that literature is instrumental to the development of an 'ethics of the empathetic imagination'. Literature illustrates, and often propounds widely shared cultural beliefs. But literature's association with any cultural system is also manifest $a$ contrario, in the fact that it interrogates and challenges the very logic, codes, and elements of the system, not only at the level of characters' values and behavior, but also starting from the writer's special use of language and narrative strategies. The pluri-vocal quality of complex literature enhances the perception of widely different subject positions and becomes a powerful tool of resistance against prejudice in favour of a sophisticated assessment of alterity. This thesis will be argued also with reference to Virginia Woolf's The Voyage Out, and special attention will be paid to the novel's empathetic dismantling of a dominator's colonial mentality. The antithetical positions of the narrator and most of the characters allows for a scathing and subtle critique of the colonial mentality.

\section{Literature and an Ethics of the Empathetic Imagination}

One of the major early contributions to the modern idea of empathy comes from The Scottish Enlightenment, a movement which includes David Hume, Francis Hutcheson, Adam Smith, Thomas Reid and Adam Ferguson, and which paved the way to what was to become the new Romantic sensibility in both ethics and aesthetics. In his Essay on the Nature and 
Conduct of the Passions with Illustrations on the Moral Sense (London 1728), Hutcheson argued against Hobbes' view of ingrained human selfishness and proposed that the quintessence of the human is benevolence and a pursuit of the happiness of others. His views spawned new approaches in ethics and aesthetics eventually developing into a new Romantic perspective.

With the advent of Romanticism, literature came to be appreciated for its power of creating empathy in connection with its imaginative dimension. In Percy Bysshe Shelley's famous words: "The great instrument of moral good is the imagination; and poetry administers to the effect by acting upon the cause" (Shelley 1970: 216-217). What I would call the new "ethics of the empathetic imagination" displaced the former neoclassical "ethics of retribution", based on the rhetorical imperative of docere et delectare, and resulting in a kind of literature in which good deeds were expected to be rewarded and bad deeds to be punished. For the Romantics literature was still at the heart of the ethical predicament, but in an entirely novel way ${ }^{1}$.

The long wave of the Romantic perspective has reached into the postmodern and the posthuman epistemic and ethical context ${ }^{2}$ where empathy has become one of the central concerns of new approaches to the understanding of the emotions in both philosophy and the cognitive sciences ${ }^{3}$. The philosopher Martha Nussbaum has recently defended the eudemonistic value of literature precisely in terms of its empathetic effects, i.e. of its power to allow readers to enter imaginatively into the life of distant others. Nussbaum's position recalls P. B. Shelley's Defence of Poetry both in its emphasis on literary empathy and on several other points, for instance when she opposes an abstract rule-governed moral reasoning to the empathetic imagining provided by literature ${ }^{4}$.

With reference to recent findings in narratology and the cognitive sciences Vera Nünning has suggested that:

[t]he comprehension of fictional stories depends on and evokes empathic feelings: without a certain amount of being able to feel like a character, it is impossible to understand him or her, let alone his or her actions. Empathy is therefore a key to comprehending characters and their actions (Nünning 2014: 104, emphasis mine).

Riane Eisler's approach to innovative social theory and her view of the contrast between a pernicious dominator's culture (to be rejected) and a valuable partnership culture (to be fostered in both the private and the public sphere) is also grounded in the concept of empathy ${ }^{5}$. Antonella Riem's recent volume ${ }^{6}$ on partnership studies in Australian Literature valuably contributes to the development of this line of thought.

In a stimulating article Doris Bachmann-Medick has critically dealt with the concept

\footnotetext{
I have dealt extensively with these issues in Locatelli 2008.

See Locatelli 2014.

See Jandl, Knaller \& Schönfellner 2017.

See Nussbaum 1990, 1995 and 2001.

See Eisler 1989, 2002 and 2007.

See Riem 2017.
} 
of 'alterity' and has asked important questions on the kind of approach(es) we can take to 'alterity', according to different ideas of 'identity', 'alienation', 'otherness', and according to various processes of 'othering' in our globalized world:

How can we guarantee that alterity can be brought to the fore as a critical concept without surrendering it to any hegemonic power of definition or to an all-too-easy, general availability? [...] The cross-cultural constellations of our world today demand changed recognitions of alterities, acknowledging more than ever alterities within the Self and other productive hybridizations beyond a binary framework (Bachmann-Medick 2017: 9).

\section{Literature's Cognitive and Aesthetic Challenges to Unquestioned 'Values'}

The involvement of literature with any system of values is visible in the fact that literature illustrates, and often propounds, beliefs that are shared within a culture (this is, of course, a case of docere et delectare towards the goals that a culture chooses to embody). But literature's association with any cultural system is also manifest a contrario, i.e., in the fact that literature interrogates and challenges the very logic, codes, and elements of the system, not only at the level of character, but also starting from the writer's special use of language and narrative strategies.

Characters in a novel, play or poem illustrate and usually impart to readers notions of normative, desirable, acceptable behavior (but, of course, what is desirable in a dominator's culture is far from acceptable in a partnership perspective). However, characters may question what is socially valued and what is taken for granted and suggest alternative ways of being in the world. This is how a critique of the dominator's mentality is made possible, whenever literature is able to resist entrenched indifference, and even hostility to the pleas of distant others (women, migrants, minorities). This can happen, provided that literature offers a plurality of perspectives on the fictional world, whereby the reader is invited to imagine both what a character feels in a certain situation, as well as what s/he would feel in the same situation. This valuable perspective-taking is one aspect of the issue that the cognitive sciences have pronounced crucial in reducing prejudice ${ }^{7}$.

Moreover, in literary texts resistance to the blind adoption of authoritarian, biased, and oppressive views is uniquely sustained by formal complexity. In Proust et les signes, Deleuze puts forward his well-known thesis that the poet speaks a foreign tongue in his own language $^{8}$. In Critique et clinique $^{9}$ he proposes a view of style as a stuttering of the language, as a tension of language towards its limits. Style can also be seen as a-grammaticality, i.e., as a resistance of the speaker/writer against the impositions and constraints of the standard language.

In a dominator's society (sensu Eisler) the resistance induced by literary readings against the mainstream doxa is a premise to the development of alternative cultural models,

\footnotetext{
7 See Elgin 2007, Batson 2009, Johnson, Jasper, Griffin \& Huffman 2013.

8 See Deleuze 1964.

9 See Deleuze 1993.
} 
including, first and foremost, the model of equitable and just relationships and the perception of hybrid identities.

Let me illustrate these dynamics with reference to a passage in Chapter 7, almost a digression, but an amazingly significant one, in Virginia Woolf's The Voyage Out.

\section{A Plurivocal Representation of the Colonial Mentality}

In Viginia Woolf's first novel (1915), the depiction of the two cultural traits of misogyny and a colonial dominator's mentality is purposefully dealt with in a sort of narrative parallelism. The male protagonist, Terence Hewet, is the mouthpiece of some of Woolf's feminist views that were to be expressed more extensively in A Room of One's Own (1929) and Three Guineas (1938). Terence becomes the strongest voice against male chauvinism while engaged in creating a true partnership relationship with his beloved Rachel Vinrace. Their open, sincere, and dialogical relationship represents a quietly provocative counterpart to the patriarchal (i.e. dominator's) view of a conventional marriage as the (only) 'happy ending' of all male-female relationships. What both the hero and the heroine are seeking is no longer marriage as the most satisfactory outcome of the canonical love plot, but the fully lived and explored experience of 'being in love', and of gaining a deeper awareness of themselves and the world surrounding them. This unusual narrative choice (certainly more transgressive in Edwardian England than it is today) still forces the reader to 'think out of the box' of the dominant mind-set, i.e., against the grain of the timeless strict prescriptions on masculine and feminine roles.

Among the many narrative innovations of the novel, one has hardly been noticed by critics, and will be my main focus in the pages that follow: it is the fact that the reader is invited to experience the 'voyage out' as an instance of direct contact with cultural difference. The voyage is directed 'out', both spatially and metaphorically; i.e., it is oriented towards a symbolical alterity embodied in a distant geographical site and in an anthropological new setting. It is thus, for both characters and readers, an experience of defamiliarisation, a test, and an instrument towards intellectual honesty and cognitive sophistication, and ultimately towards the questioning of a narrow (Edwardian, British and Eurocentric) cultural perspective.

Most of the characters in the novel, i.e., the group of English travelers who come on the Euphrosyne ${ }^{10}$ to Santa Marina, embody this biased ideological dimension and unquestioningly uphold it, because ideology often operates in terms of 'naturalizing' its assumptions, and tendentiously making what is culturally construed look natural, and universal. The majority of the English visitors to the tropical region fail to openly question the perspective of the ultraconservative Mr. Pepper, the pedantic, misogynous scholar who is, not surprisingly, a nostalgic promoter of British imperialism. And yet, what is significant in the novel is that the narrator's dissenting point of view is magisterially inscribed within the outspoken imperialist views of the character(s). In other words, the ideological clash between narrator and character is, remarkably, as sharp as it is subtle.

10 Euphrosyne in Greek mythology was one of the three Graces, the goddess of good cheer and merriment. She was also the goddess of chastity. 
The narrator's judgment and negative evaluation of Mr. Pepper's words is not an ostentatious condemnation, a flat, dogmatic moral statement, but it is conveyed through the elaborate form given to the narrative while reporting the character's thoughts and speech. This is a clear instance of literary complexity ${ }^{11}$, and of literature's power of saying more than one thing at the same time, and even of saying contradictory things simultaneously. In fact, the narrator's point of view and Pepper's imperialist ideology are juxtaposed in such a way that their discrepancies are brought to the fore. There is an oscillation between the narrator's omniscent's position and the characters' thoughts that are not voiced aloud.

This inscription of ideological dissent in an apparently linear narration is an illuminating example of the plurivocal and multi-perspectival dimension of literary discourse, a strategy that challenges the readers in their taken-for-granted assumptions. In this sense, plurivocality can transform unchallenged bias, both at a cognitive and ethical level.

Ultimately, this novel is an effective means of reducing prejudice (sensu Johnson, Jasper, Griffin \& Huffman 2013), because prejudice, in the form of both male chauvinism and colonial arrogance, is stigmatized through Woolf's subtle irony. This is the point at which Eisler's philosophical views in The Chalice and The Blade and Woolf's literary discourse in The Voyage Out come to a clear and strong convergence. Both the novelist and the philosopher convincingly propose that the exploitation of another human being or ethnic group, and the so called 'war of the sexes' based on male dominance are not biologically determined or sanctioned by divine decree, but that, on the contrary, they are the bitter fruit of specific cultural practices of oppression.

Let me now provide a detailed analysis of a few passages in the novel that I see as both a simultaneous illustration and challenge of the imperialist predicament. While describing the commotion of arrival at Santa Marina, the omniscient narrator notes, almost in passing, that: "The lonely little island was invaded from all quarters at once" (Woolf 1989: 85). But 'invaded' is obviously an adjective chosen because charged with colonial connotations, despite the fact that the newcomers are supposedly 'harmless' visitors. The novel invites (without preaching) an ethical attitude of attention and respect towards 'the other', and may even suggest (to readers in our times) that Western tourism may not be entirely free from its colonial legacy ("Somehow or other, as fashions do, the fashion spread; an old monastery was quickly turned into a hotel, while a famous line of steamships altered its route for the convenience of passengers", Woolf 1989: 88) ${ }^{12}$.

The arrival of the cargo boat at Santa Marina is described from the point of view of previously arrived passengers who observe it from more prestigious ships. Class is clearly one among the many discrimination criteria that promote an attitude of complacent superiority among the upper classes.

From a distance the Euphrosyne looked very small. Glasses were turned upon her from the decks of great liners, and she was pronounced a tramp, a cargo-boat, or one of those wretched little passenger steamers where people rolled about among the cat-

\footnotetext{
11 See Locatelli 2009.

12 See Bhabha 1994 and Geertz 1983.
} 
tle on deck. The insect-like figures of Dalloways, Ambroses, and Vinraces were also derided, both from the extreme smallness of their persons and the doubt which only strong glasses could dispel as to whether they were really live creatures or only lumps on the rigging (Woolf 1989: 85).

The snobbery of the privileged anticipates the general British attitude towards alterity, from which the party that disembarks on the island is not immune. The passengers of the Euphrosyne, the despised, will soon display the same smug attitude towards the natives, a recurring trait that eventually escalates to open racist insult and to imperialist pronouncements, grounded in the Victorian doctrine of 'the white man's burden'.

The gaze of the Western visitors defines the exotic space, but the narrator's omniscient voice intermingles, interferes with, and meta-comments their perceptions. Virginia Woolf's is a multi-level narrative that allows for both the voicing of prejudice (in the mouth and minds of the characters) and a distancing from such biases in the narrator's comments on their attitudes. The English travelers are surprised to find, after the sea voyage, so many "minute object" and "different forms of life" around them (Woolf 1989: 86). The primary objects of their gaze are: the hills, the mountains, the rich vegetation and the little white houses with brown roofs "settled, like nesting sea birds" (Woolf 1989: 86), which implies a perfect ecological integration of human activity and natural landscape. The simile "like nesting sea birds" suggests harmony; is it something that the newcomers think? Or, more likely, the point of view of the narrator who takes charge of the description?

This double and even plural narrative strategy is further enhanced in the passage that follows, when the silence is broken by Mr. Pepper: his thoughts are given full scope by the perceptive narrator, whose opinions diverge from those of this quintessentially 'dominator' and complacent character. Narratorial dissent gradually becomes more and more evident, and turns into a profound and thorough critique of the colonial attitude, as demonstrated in the following quotation:

"Three hundred years odd", said Mr. Pepper meditatively at length.

As nobody said, "What?" he merely extracted a bottle and swallowed a pill. The piece of information that died within him was to the effect that three hundred years ago five Elizabethan barques had anchored where the Euphrosyne now floated. Half-drawn up upon the beach lay an equal number of Spanish galleons, unmanned, for the country was still a virgin land behind a veil (Woolf 1989: 86).

Pepper's recollections open with the idea that when the English sailors arrived, Spanish galleons were already anchored in the bay. Virginia Woolf's fiction provides an accurate historical information, since the Spaniards and Portuguese had arrived to Central and South America at least eighty years before the English. The metaphor of the "virgin land behind a veil" belongs to mainstream colonial discourse of the colonisation exalting male prowess and domination over the land and local women, but in this passage the trope also illustrates its critical counterpart, which condemns colonisation as the rape of a shy, and presumably reluctant ("veiled") virgin. 
The story of the British conquest of the world is succinctly and imaginatively recounted in the single episode of what had supposedly happened in Santa Marina, but the episode is emblematic of the entire colonial enterprise: "Slipping across the water, the English sailors bore away bars of silver, bales of linen, timbers of cedar wood, golden crucifixes knobbed with emeralds" (Woolf 1989: 86). Colonisation starts and thrives as pillage. The English rob precious goods and artefacts (appreciated more for their worth in gold and emeralds than by their symbolic value); on the other hand, the informed reader recalls that the Spaniards had in turn despoiled the natives of their treasures to make their own precious artefacts. The whole history of colonialism is represented in this very brief fiction through the events on "the little island" (Woolf 1989: 95). It is a compact digression in the whole novel, one that, however, cannot be ignored if we are not just reading for the plot. The passage below also alludes to the fact that English pirate ships routinely attacked Spanish galleons richly loaded with colonial treasures. History tells us that the fight between the two was an inevitable outcome. This is metaphorically rendered in the novel as an image of a bodily fight on the shore of Santa Marina between the "drunken" Spaniards, overfed by the plentiful fruits of the "miraculous" land, and the "hardy", "tawny", "hairy" English, "with muscles like wire":

When the Spaniards came down from their drinking, a fight ensued, the two parties churning up the sand, and driving each other into the surf. The Spaniards, bloated with fine living upon the fruits of the miraculous land, fell in heaps; but the hardy Englishmen, tawny with sea-voyaging, hairy for lack of razors, with muscles like wire, fangs greedy for flesh, and fingers itching for gold, dispatched the wounded, drove the dying into the sea, and soon reduced the natives to a state of superstitious wonderment (Woolf 1989: 86-87).

The negative stereotypical image of the enemies ("drunken" and "bloated"), is of course Dr. Pepper's, as well as the macho and chauvinist picture of the English, clearly in line with his overt 'dominator' ideology (sensu Eisler). But a counter-image is inserted in the very portrait of English conquerors: their ruthless ravenousness is explicit in their "fangs greedy for flesh", and their obsession with gain is clear in the metaphor of their "fingers itching for gold". Greed and cruelty are the historical elements of a perverse course of events that Woolf's fiction does not wish to ignore. Moreover, the "superstitious wonderment" of the natives and their supposed cultural inferiority has, of course, been a classical topos of colonial discourse, since Thomas Hariot's famous travelogue A Brief and True Report of the Newfound Land of Virginia (1588) ${ }^{13}$. As I have argued elsewhere ${ }^{14}$, the disciplinary ideology shaping English subjects at home (including their recognition of the king's authority and the ensuing pride in national identity) is taken a step further in the parallel process of the submission of the alien others abroad. The latter are not, however interpellated as subjects (Lecercle 2019) in the affirmative sense (subjectivité) but they remain subjects in the sense of

13 Thomas Hariot took part in Sir Richard Grenville's expedition in 1585 and his travelogue is often mentioned as one of the sources of Shakespeare's Tempest.

14 See Locatelli 2001, in which I have dealt with cultural strategies of inclusion/exclusion, stereotyping, labelling, etc. 
assujettisement, i.e. as servants of the dominators. The English subject, in the very moment of his/her interpellation as such, feels entitled to force the 'Other' to recognize the subjectivity and superiority of the English. Thomas Hariot writes: "There is good hope they may be brought through discreet dealing and gouernement to the imbracing of the trueth, and consequently to honor, obey, feare and loue us" (Hariot 1903: 69).

The dominators' ideology (sensu Eisler) is thus fully displayed in the dichotomy 'us'versus 'them', and its concomitant hierarchization of cultural difference, whereby 'different' is meant as 'inferior' (Bhabha 1994): Pepper is clearly moving in Hariot's footsteps. His delight in the success of English colonisation and his disappointment that it was not more extensive ("the map would undoubtedly be red where it is now an odious green"15, Woolf 1989: 87) registers the widespread Edwardian and Georgian anxieties on the destiny of the empire, and a parallel nostalgia for its Victorian climax:

\begin{abstract}
Here a settlement was made; women were imported; children grew. All seemed to favour the expansion of the British Empire, and had there been men like Richard Dalloway in the time of Charles the First, the map would undoubtedly be red where it is now an odious green. But it must be supposed that the political mind of that age lacked imagination, and, merely for want of a few thousand pounds and a few thousand men, the spark died that should have been a conflagration. [...]

From the interior came Indians with subtle poisons, naked bodies, and painted idols; from the sea came vengeful Spaniards and rapacious Portuguese; exposed to all these enemies (though the climate proved wonderfully kind and the earth abundant) the English dwindled away and all but disappeared. [...] English history then denies all knowledge of the place (Woolf 1989: 87).
\end{abstract}

The imperialist mind wishes for a continuous escalation of the conquest (metaphorically not just "a spark" but "a conflagration"). Stereotypical negative labelling is applied to natives and to enemies alike: the natives are idolatrous (which signals the English lack of respect for different cultures and beliefs), the Spaniards are "vengeful" and the Portuguese "rapacious". Projecting onto the enemy the traits that a culture does not admit as its own is a classical strategy to exalt one's own image and denigrate the other.

Fear is undoubtedly a prevailing emotion towards the Other in the colonial mindset. Woolf's keen perception and critique of the contemporary imperialist ideology goes even further: it includes an observation as to the fact that nationalist discourse is repressing all historical knowledge of the "dark" pages concerning the waning of British settlements and the causes of the gradual dismantling of "the great British colony". The implications of this historiographical omission are highlighted in the following consideration (most likely from the narrator's rather than from Pepper's own musing): "[...] The reasons which had drawn the English across the sea to found a small colony within the last ten years are not so easily described, and will never perhaps be recorded in history books" (Woolf 1989: 87).

Woolf is certainly ahead of her times when, within a fictional narrative and a relatively

15 Pepper alludes to the fact that red indicates colonial possessions in maps of the British Empire. It is interesting to note that green, a traditional attribute of nature, is assigned to the territories that do not belong to it. 
short but not marginal digression, she manages to meta-comment the omissions of official historiography. Historians have only fairy recently begun to interrogate the forms of history books that have generally been taken for 'factual' truth, when they merely represent the truth of the winners. It is indeed striking that Woolf is able to represent the positions and motives that are responsible for reticent and omissive historiography, and that she does so through an exquisitely 'literary' style, i.e. through a special use of language, and complex emplotment strategies.

The history of colonisation that is told at home requires the oblivion of violence against the natives and includes the myth of the plentiful and beautiful New World, an obvious incentive to prospective settlers. The narrator suggests that schoolmasters played a central role in the enterprise: they are significant agents of the reduction of 'the Other' into a subordinate subject:

The movement in search of something new was of course infinitely small, affecting only a handful of well-to-do people. It began by a few schoolmasters serving their passage out to South America as the pursers of tramp steamers. [...] The country itself taxed all their powers of description, for they said it was much bigger than Italy, and really nobler than Greece. Again, they declared that the natives were strangely beautiful, very big in stature, dark, passionate, and quick to seize the knife. The place seemed new and full of new forms of beauty, in proof of which they showed handkerchiefs which the women had worn round their heads, and primitive carvings coloured bright greens and blues. Somehow or other, as fashions do, the fashion spread; an old monastery was quickly turned into a hotel, while a famous line of steamships altered its route for the convenience of passengers (Woolf 1989: 88).

Edward Said's Orientalism comes to mind (Said 1978) when the narrator acutely suggests that people are attracted to exotic places by the couleur locale, a "fashion", rather than by a serious desire to meet 'the Other'. The lack of respect and the philistine complete disregard for the sacred is evident in the adjective "primitive" applied to the indigenous carvings, and in the turning of an old monastery into a hotel. Other motives of colonial settlement are represented by Helen Ambrose's brother who "had been sent out years before to make his fortune, at any rate to keep clear of race-horses" (Woolf 1989: 88). A clean break with the past does not per se imply a transformative encounter with the other. In fact, the English prejudice engrained in the group disembarked from the Euphrosyne is further expressed by their superficial and stereotypical gaze on the local village:

The road passed through the town, where men seemed to be beating brass and crying "Water", where the passage was blocked by mules and cleared by whips and curses, where the women walked barefoot, their heads balancing baskets, and cripples hastily displayed mutilated members (Woolf 1989: 89).

The party's negative evaluation of the villa and its wilting garden is grounded in their obtuse persuasion that an English house and garden should be transplanted in a tropical region to improve it. The disappointment of the English in what they find 'different' is evident: 
The villa was a roomy white house, which, as is the case with most continental houses, looked to an English eye frail, ramshackle, and absurdly frivolous, more like a pagoda in a tea-garden than a place where one slept. The garden called urgently for the services of gardener (Woolf 1989: 89).

A new focaliser, Mrs Chailey becomes the strongest voice of prejudice. She embodies the "political economy of difference", discussed in Rosi Braidotti's The Posthuman, whereby "entire categories of human beings" were devalued as "disposable others", since "to be 'different from' came to mean 'less than'" (Braidotti 2013: 28). Woolf writes:

The indecency of the whole place struck Mrs Chailey forcibly. There were no blinds to shut out the sun, nor was there any furniture to speak of for the sun to spoil. Standing in the bare stone hall, and surveying a staircase of superb breadth, but cracked and carpetless, she further ventured the opinion that there were rats, as large as terriers at home, and that if one put one's foot down with any force one would come through the floor. As for hot water - at this point her investigations left her speechless.

"Poor creature!" she murmured to the sallow Spanish servant-girl who came out with the pigs and hens to receive them, "no wonder you hardly look like a human being!" Maria accepted the compliment with an exquisite Spanish grace (Woolf 1989: 90).

Mrs Chailey's racist insult, degrading the kind and welcoming Spanish girl to the level of the non-human, is explicitly contradicted by the perceptive and dissenting narrator, who notes that "Maria accepted the compliment with an exquisite Spanish grace", thereby suggesting that Maria is more accomplished than her interlocutor (who obviously fails to recognize her "grace" probably because the girl appeared in the lowly context of pigs and hens). Poverty is callously taken for a mark of intellectual and moral inferiority in the biased mentality voiced by Mrs Chailey.

As the above passages demonstrate, an adjective, an adverb, a syntactical deviation from the standard language, i.e. the specificity of literary form suffices to compel readers to pause and think of the nature and meaning of historical narrations, and the partisan positions implicit in them. The passages quoted above provide a critical perspective on colonialism that anticipates the future progress in anthropology, and even aspects of 'post-colonial' theory.

Let me just conclude by recalling one of Antonella Riem's statements on 'the liberating power of storytelling':

I see literature as a gift of partnership. It carries the instruments of knowledge, consciousness, passion, creative power to imagine, re-imagine and trans-form our world, our relationship with ourselves and others - meaning not only the human other, but also the animal, vegetal and the living planet Gaia (Riem 2017: 198).

I take this statement as a fit point of arrival for my line of reasoning, and as corroborating my view that literature is a beneficial ecological space to be preserved in our global techno-bureaucratic environment. Literature is certainly not antithetical to the demands of 
science, but it provides a unique contribution not only to the development of emotional and intellectual sophistication, but also to the enhancement of our problem-solving faculties, hopefully oriented towards the construction of the more just and compassionate world advocated by Riane Eisler.

\section{BIBLIOGRAPHY}

Bachmann-Medick, Doris. 2017. Alterity - A Category of Practice and Analysis. Preliminary Remarks. On_Culture: The Open Journal for the Study of Culture, 4: 1-12. http:/ / geb.uni-giessen.de/geb/volltexte/2017/13387/ (consulted on 3/06/2019).

Batson, C. D. 2009. Two forms of perspective taking: Imagining how another feels and imagining how you would feel. K. D. Markman, W. M. P. Klein \& J. A. Suhr eds. Handbook of imagination and mental simulation. New York: Psychology Press, 267-279.

Bhabha, Homi K. 1994. The Location of Culture. London-New York: Routledge.

Braidotti, Rosi. 2013. The Posthuman. Cambridge: Polity Press.

Deleuze, Gilles. 1964. Proust et les signes. Paris: PUF.

Deleuze, Gilles. Critique et clinique. Paris: Minuit.

Eisler, Riane. 1989. The Chalice and The Blade: Our History, Our Future. New York: Harper \& Row.

Eisler, Riane. 2002. The Power of Partnership: Seven Relationships that will Change Your Life. Novato (CA): New World Library.

Eisler, Riane. 2007. The Real Wealth of Nations: Creating a Caring Economics. San Francisco: Berrett-Koehler.

Elgin, Catherine. 2007. The laboratory of the mind. Wolfgang Huemer, John Gibson \& Luca Pocci eds. A Sense of the World: Essays on Fiction, Narrative and Knowledge. London-New York: Routledge, 43-54.

Geertz, Clifford. 1983. Local Knowledge. New York: Basic Books.

Hariot, Thomas.1903. A Briefe Report of the Newfound Land of Virginia by Thomas Hariot. Reproduced in Facsimile from the First Edition of 1588. New York: Dodd, Mead \& C., https: / / archive. org/stream/abriefeandtruer00harigoog\#page/n12/mode/2up (consulted on 23/09/2019). Hutcheson, Francis. 1728. Essay on the Nature and Conduct of the Passions with Illustrations on the Moral Sense. London: J. Osborn \& T. Logman, https://archive.org/details/essayonnaturecon00hutciala (consulted on 3/06/2019).

Jandl, Ingeborg, Susanne Knaller, Sabine Schönfellner \& Gudrun Tockner eds. 2017. Writing Emotions. Theoretical Concepts and Selected Case Studies in Literature. Bielefeld: Transcript Verlag. Johnson, D. R., D. M. Jaspers, S. Griffin \& B. Huffman. 2013. Reading narrative fiction reduces Arab-Muslim prejudice and offers a safe haven from intergroup anxiety. Social Cognition, 31: 578- 598.

Lecercle, Jean-Jacques. 2019. De l'interpellation. Sujet, langue, idéologie. Paris: Editions Amsterdam.

Locatelli, Angela. 2001. 'English Matter, in the English Tongue, for Englishmen'. Lingua, retorica e poetica dell'identità nazionale nel rinascimento inglese. Alessandra Marzola (a cura di). Racconti di Identità. Bergamo: Sestante-Bergamo University Press, 13-34. 
Locatelli, Angela. 2008. Literature's Versions of its Own Transmission of Values. Astrid Erll, Herbert Grabes \& Ansgar Nünning eds. Ethics in Culture. Berlin: de Gruyter, 19-34.

Locatelli, Angela. 2009. The Ethical Use(s) of Literary Complexity. Sibylle Baumbach, Herbert Grabes \& Ansgar Nünning eds. Values in Literature and the Value of Literature: Literature as a Medium for Representing, Disseminating and Constructing Norms and Values. Trier: Wissenschaftlicher Verlag Trier, 67-76.

Locatelli, Angela. 2014. Reading Literature: An Ethical Gesture in the Postmodern Context? Armenia Folia Anglistika, 12, 1: 121-130.

Nünning, Vera. 2014. Reading Fictions, Changing Minds. The Cognitive Value of Fiction. Heidelberg: Universitätsverlag Winter.

Nussbaum, Martha C. 1990. Love's Knowledge: Essays on Philosophy and Literature. New York: Oxford University Press.

Nussbaum, Martha C. 1995. Poetic Justice: The Literary Imagination and Public Life. Boston: Beacon Press.

Nussbaum, Martha C. 2001. Upheavals of Thought: The Intelligence of the Emotions. Cambridge-New York: Cambridge University Press.

Riem, Antonella. 2017. A Gesture of Reconciliation: Partnership Studies in Australian Literature. Udine: Forum.

Said, Edward. 1978. Orientalism. London-New York: Routledge.

Shelley, Percy Bysshe. 1970. A Defence of Poetry.1840. Ernest Rhys ed. The Prelude to Poetry. The English Poets in Defence and Praise of their own Art. London: Dent \& Sons, 207-241.

Woolf, Virginia. 1989 [1915]. The Voyage Out. London: Grafton Books.

Woolf, Virginia. 1929. A Room of One's Own. London: Hogarth Press.

Woolf, Virginia. 1938. Three Guineas. London: Hogarth Press.

Angela Locatelli is Full Professor of English Literature at the University of Bergamo, where she was Director of the Department of Languages and Comparative Literatures (1999-2006) and Director of the PhD Program in "Euro-American Literatures" (2009-2018). She is also adjunct Professor in the Department of Religious Studies at the University of Pennsylvania, Philadelphia, and one of the founding members of the International PhD Network connecting the University of Giessen (Germany) with the Universities of Bergamo, Helsinki, Stockholm, Graz, and The Catholic University of Portugal in Lisbon. She is on the Editorial Board of Armenian Folia Anglistika and was on the Editorial Board of EJES The European Journal of English Studies. In 1999 and 2008 She was awarded two Fellowships at the Folger Shakespeare Library in Washington D. C. Her main research interests are literary and cultural theory. She edited ten volumes on literary epistemology (The Knowledge of Literature/ La conoscenza della Letteratura, 2002-2011, Sestante Edizioni) and has written extensively on Shakespeare and Renaissance culture and literature. Her international publications also include a book on the "stream of consciousness" novel and several articles on Modernist, Postmodern fiction and 20th Century drama.

angela.locatelli@unibg.it 